\title{
Antimicrobial Resistance of Clinical and Environmental Strains of Vibrio cholerae Isolated in Lima-Peru During Epidemics of 1991 and 1998
}

\author{
Ibarra J.O. ${ }^{1}$, Alvarado D.E. ${ }^{2}$ \\ ${ }^{1}$ Natural Science and Mathematics College, Federico Villarreal National University; \\ ${ }^{1}$ Biological Sciences College, National University of San Marcos; Lima, Peru
}

\begin{abstract}
The susceptibility in vitro of 71 isolations of $V$. cholerae was evaluated: 24 of clinical origin and 47 strains of clinical and environmental origin collected in the epidemic of 1991 and during the outbreak epidemic of 1998 in Lima-Peru respectively. The biochemical and serological tests carried out established that $43(60,6 \%)$ corresponded to the serogroup 01 Ogawa of the 1998 epidemic; 26 (36.6\%) were of the serotype Inaba, being 24 of them isolated in 1991. Two strains did not belong to the serogroup 01. By means of disk diffusion method and Minimal Inhibitory Concentration (MIC), 15 strains with multi-resistance to antibiotics were determined, 10 of which were of clinical origin and 5 of natural origin, showing 9 antibiotypes with different resistance pattern. The evaluation of susceptibility in front of the vibriostatic agent $\mathrm{O} / \mathbf{1 2 9}$, demonstrated that $11.4 \%$ of the strains, collected in 1998 , presented resistance to a concentration of $150 \mu \mathrm{g}$. A direct relationship among the resistance that presented the strains of clinical and environmental origin isolated in 1991 and 1998 was established as much for tetracycline, sulfa/trimethoprim and 0 / 129; $88.6 \%$ of the clinical strains of the year 1998 presented resistance to these three drugs, while $100 \%$ of clinical strains isolated in 1991 were sensitive to $\mathrm{O} / 129(150 \mu \mathrm{g})$, sulfa/trimethoprim and tetracycline. We conclude that $V$. cholerae $\mathrm{O1}$ has increased its resistance to antimicrobial drugs of clinical use in the same way it is also losing susceptibility to the vibriostatic compound $\mathrm{O} / 129$ for what their use is not recommended for taxonomic purposes. Key-Words: Vibrio cholerae, antimicrobial resistance, cholera outbreak.
\end{abstract}

Cholera, the most terrible of all diarrhoeic illnesses, is an acute intestinal infection, caused by Vibrio cholerae of serogroups $\mathrm{O} 1$ and $\mathrm{O} 139$, a bacteria which is present in a variety of aquatic environments [1,2]. Serogroups non-O1 and non-O139 are mostly related with sporadic diarrheas and extraintestinal infection $[3,4]$. The description of $V$. cholerae for taxonomic studies includes identification to the genus level, $\mathrm{O} / 129$ vibriostatic agent sensibility, among others; different biochemical tests and morphologic characteristics which contribute to an accurate identification of the species and serological tests which may differentiate them in groups and types.

The resistance of this bacteria to several antimicrobial drugs has been frequently reported in samples of clinical origin as well as of environmental origin in different endemic areas around the world [5-7]. The O/129 vibriostatic compound is used for taxonomic identification of members of the family Vibrionaceae and of some species of Vibrio genera from clinical sources, $99 \%$ of strains of $V$. cholerae $\mathrm{O} 1$ has been reported as sensitive to the O/129 [6]. Different reports have described resistance to this vibriostatic agent in clinical and environmental strains [7-11].

Since the cholera reappeared in Peru in the summer of 1991, the epidemic stopped adapting itself to the existent climatic conditions in our country until it became endemic nowadays [12]. In 1998 an outbreak of cholera took place as a result of the appearance of "El Niño Oscillation Southern"

Received on 12 April 2006; revised 6 December 2006.

Address for correspondence: Dr. Alvarado, A.E. E-mail: dalvaradoi@unmsm.edu.pe.

The Brazilian Journal of Infectious Diseases 2007;11(1):100-105. (C) 2007 by The Brazilian Journal of Infectious Diseases and Contexto Publishing. All rights reserved.
(ENSO). In the last years in the country, several studies have been carried out in relation to antibiotic susceptibility of $V$. cholerae. In none of these a comparative study was achieved among the strains which were isolated in the two different periods of appearance of the illness [13-15].

The aim of this study was to evaluate the resistance to different antimicrobial drugs of strains of $V$. cholerae isolated in Lima of clinical and environmental samples during the years 1991 and 1998. These analyses would contribute to the knowledge of the epidemiology of Vibrio cholerae and will help professionals understand each one better as this bacteria goes on adapting itself to the existent climatic conditions in Peru.

\section{Materials and Methods}

Strains

The biological material belongs to the collection of the Laboratory of Molecular Microbiology of the College of Biological Sciences - UNMSM [14] and of the Public Health Institute (INS-Peru). The strains used in this study were: 35 of $V$. cholerae of clinical origin, isolated in the outbreak epidemic 1998 of cholera in the country; 12 strains isolated in the river Rimac, main source of water of Lima, in 1998; and 23 strains obtained of the outbreak epidemic of 1991 (National Institute of Health, Peru). The following reference strains were used: $E$. coli ATCC 25922, V. cholerae O1 ATCC 14033, V. harveyi ATCC 14126, P. aeruginosa ATCC 27853 and S. aureus ATCC 25923. The strains were reactivated in Luria both containing $1 \% \mathrm{NaCl}$ and incubated for 18 at 24 hours to $37^{\circ} \mathrm{C}$ and were spread on plates of Caso agar to verify viability and purity

\section{Taxonomic Identification of the Strains}

The tests used for genera and species identification are those recommended in the Bergey's Manual and for the 
Maryland Biotechnology Institute [6,16]. The morphologic study was carried out using the Gram technique and Leifson staining for flagella. The serologic tests were made using the slide agglutination technique, with polivalent antisera for V.cholerae serogroup $\mathrm{O} 1$ and monovalents for serotypes Inaba and Ogawa (National Institute of Health, Peru).

\section{Sensitivity to Vibriostatic Compound O/129}

It was carried out by means of the Disk Diffusion technique in agar, by modified placing disks of paper filter, absorbed with the vibriostatic compound O/129, on sterile Petri plates. The concentrations that were used for this test were 10 and $150 \mu$ g. The susceptibility to the O/129 agent was evaluated by the presence of a clear zone of inhibition around the disks; the resistant organisms didn't develop inhibition area.

\section{Antibiotic Susceptibility Testing}

All strains were tested for antibiotic susceptibility to 10 antibacterial drugs by Disk Diffusion on Mueller-Hinton Agar with disks (Andina Médica, Chile) containing ( $\mu \mathrm{g} /$ disk) ampicillin $(10 \mu \mathrm{g})$, chloramphenicol $(30 \mu \mathrm{g})$, ciprofloxacine

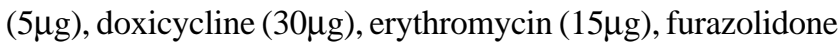
$(100 \mu \mathrm{g})$, nalidixic acid $(30 \mu \mathrm{g})$, streptomycin $(10 \mu \mathrm{g})$, tetracycline $(30 \mu \mathrm{g})$, trimethoprim/sulfamethiazole $(25 \mu \mathrm{g})$. Antibiotic susceptibility testing was carried out by the BauerKirby method [17] and strains were recorded as sensitive, intermediate or resistant according to the interpretation criteria recommended by the National Committee for Clinical Laboratory Standards (NCCLS, 2004) [18].

To determine the Minimum Inhibitory Concentration (MIC) of the strains, the method of Dilution in Agar was used [19]. The isolated ones that were resistant and a selection in aleatory form of strains that were recorded previously as intermediate and sensitive with the disk diffusion method, were evaluated to determine the MIC, according to the recommended interpretive criteria by the NCCLS [18].

\section{Results}

The 71 isolations examined in the present report were confirmed as Vibrio cholerae according to the results of the biochemical tests recommended for identification. (Table 1). The results of the serologic tests showed that 43 (60.6\%) strains out of all strains examined corresponded to the serogroup $\mathrm{O} 1$ serotype Ogawa, all of these belonging to the epidemic outbreak of 1998. Out of those which were included, many clinical strains have environmental origin. The 24 (33.8\%) strains isolated in the epidemic of 1991 belong to the serotype Inaba; only 2 strains of clinical origin isolated in 1998 were located in this serotype (Table 2). It is necessary to point out that only 2 analyzed strains (2.8\%) didn't belong to the serogroup O1 and were isolated in 1998, both of environmental origin and with the same biochemical characteristics.

The approach to consider sensitive or resistant strains of $V$. cholerae was based on the values for enterobacteria recommended by the NCCLS [19]. The 71 isolations studied
Table 1. Biochemical confirmation of Vibrio cholerae strains isolated from clinical and environmental sources, 1991-1998 $(\mathrm{n}=71)$

\begin{tabular}{lcc}
\hline Criteria & Reaction & $\mathbf{\%}$ \\
\hline Gram stain & - & $100 \%$ \\
Flagella stain & + & $100 \%$ \\
Oxidase & + & $100 \%$ \\
String test & + & $100 \%$ \\
Indole & + & $100 \%$ \\
Mobility & + & $100 \%$ \\
Descarboxilase ornithine & + & $100 \%$ \\
Red methyl 37 ${ }^{0}$ C. & $\mathrm{d}$ & $97 \%$ \\
Voges - Proskauer 370 C. & + & $80 \%$ \\
Simons's citrate & - & $100 \%$ \\
H S / TSI & - & $100 \%$ \\
Urease & + & $100 \%$ \\
Descarboxilase lysine & - & $100 \%$ \\
Dehydrolase arginine & + & $100 \%$ \\
Nitrate reduction & + & $100 \%$ \\
0\% NaCl, growth & + & $100 \%$ \\
1\% NaCl, growth & d & $700 \%$ \\
6\% NaCl, growth & - & $75 \%$ \\
8\% NaCl, growth & + & $100 \%$ \\
Gelatinase & + & $100 \%$ \\
D- Glucose, acidity & - & $100 \%$ \\
D- Glucose, gas & + & $100 \%$ \\
D- Mannitol, acidity & - & $100 \%$ \\
D- Cellobiose, acidity & - & $100 \%$ \\
D- Arabinose, acidity & $\mathrm{d}$ & $80 \%$ \\
Glycerol, acidity & - & $100 \%$ \\
Lactose, acidity & + & $100 \%$ \\
Sucrose, acidity & & \\
\hline +, > 90 \% positive; -, < 10 \% positive; d, > $10 \%$ but & $<90 \%$ \\
positive [6,16]. & & \\
& + &
\end{tabular}

Table 2. Serologic evaluation of strains of Vibrio cholerae isolated in the epidemic outbreaks of 1991 and 1998

\begin{tabular}{|c|c|c|c|c|}
\hline \multirow[t]{2}{*}{ Serotype } & \multicolumn{2}{|c|}{1991} & 1998 & \multirow[b]{2}{*}{$\begin{array}{c}\text { Total } \\
\mathrm{N}(\%)\end{array}$} \\
\hline & $\begin{array}{l}\text { Clin. } \\
\text { N(\%) }\end{array}$ & $\begin{array}{l}\text { Clin. } \\
\text { N(\%) }\end{array}$ & $\begin{array}{c}\text { Amb. } \\
\text { N(\%) }\end{array}$ & \\
\hline Inaba & 24(33.8) & $2(2.8)$ & $0(0.0)$ & 26(36.6) \\
\hline Ogawa & $0(0.0)$ & $33(46.5)$ & $10(14.1)$ & $43(60.6)$ \\
\hline No-O1 & $0(0.0)$ & $0(0.0)$ & $2(2.8)$ & $2(2.8)$ \\
\hline Total & 24(33.8) & $35(49.3)$ & $12(16.9)$ & $71(100.0)$ \\
\hline
\end{tabular}

were sensitive to ciprofloxacine and doxicicline. The strains of clinical origin isolated in 1991 were sensitive to all antibiotics, only one of them presenting resistance to ampicillin. Out of all strains isolated in 1998, 14 presented different levels of resistance to tetracycline, streptomycin, chloramphenicol, nalidixic acid, sulfa/trimethoprim, furazolidone, ampicillin and erythromycin, out of which 9 were of clinical origin and 5 environmental. When carrying out a comparison of the susceptibility among the strains of 1998 of different origins, 
Table 3. Resistance of strains of Vibrio cholerae to antibiotics of commercial use, evaluated by Disk Diffusion in Agar Method. Lima, 1998

\begin{tabular}{|c|c|c|}
\hline $\begin{array}{l}\text { Antimicrobial } \\
\text { agent }(\mu \mathrm{g})\end{array}$ & $\begin{array}{c}\begin{array}{c}\text { Clinical } \\
\text { samples } \\
\mathbf{n}=35 \\
(\%)\end{array}\end{array}$ & $\begin{array}{c}\text { Environmental } \\
\text { samples } \\
\mathbf{n}=12 \\
(\%)\end{array}$ \\
\hline Tetracycline (30) & 11.4 & 25.0 \\
\hline Chloramphenicol (30) & 5.7 & 0 \\
\hline Sulfatrimethoprim (25) & 11.4 & 16.7 \\
\hline Ampicillin (10) & 2.8 & 16.7 \\
\hline Streptomycin (10) & 11.4 & 25.0 \\
\hline Nalidixic acid (30) & 5.7 & 16.7 \\
\hline Furazolidone (100) & 8.5 & 0 \\
\hline
\end{tabular}

Table 4. Evaluation of vibriostatic agent $\mathrm{O} / 129$ in strains of environmental and clinical origin (1991 and 1998) isolated of Lima

\begin{tabular}{|c|c|c|c|c|}
\hline Concentration & $\begin{array}{c}\text { Environmental } \\
\text { Category } \\
(n=12) \%\end{array}$ & $\begin{array}{c}1991 \\
\text { strains } \\
\% \\
\end{array}$ & $\begin{array}{c}1998 \\
(n=24) \\
\% \\
\end{array}$ & $(n=35)$ \\
\hline $10 \mu \mathrm{g}$ & S & 0 & 33.3 & 14.2 \\
\hline $\mathrm{R}$ & 100 & 66.6 & 85.7 & \\
\hline $150 \mu g$ & $\mathrm{~S}$ & 66.6 & 100 & 88.5 \\
\hline $\mathrm{R}$ & 33.3 & 0 & 11.4 & \\
\hline
\end{tabular}

Table 5. Relationship among the vibriostatic agent sensibility O/129, Tetracycline and the Sulfa/Trimethoprim

\begin{tabular}{lcccccc}
\hline & \multicolumn{3}{c}{ Clinical strains } & \multicolumn{2}{c}{ Environmental strains } \\
\cline { 2 - 7 } $\begin{array}{l}\text { Antimicrobial } \\
\text { agent }\end{array}$ & $\mathbf{1 9 9 1}$ & \multicolumn{1}{c}{$\mathbf{1 9 9 8}$} & \multicolumn{2}{c}{$\mathbf{1 9 9 8}$} \\
$\mathbf{n = 2 4}$ & \multicolumn{2}{c}{$\mathbf{n = 3 5}$} & \multicolumn{2}{c}{$\mathbf{n = 1 2}$} \\
\cline { 2 - 7 } & $\mathbf{S}$ & $\mathbf{R}$ & $\mathbf{S}$ & $\mathbf{R}$ & $\mathbf{S}$ & $\mathbf{R}$ \\
\hline $\mathrm{O} / 129$ & 24 & 0 & 4 & 31 & 10 & 2 \\
$(150 \mu \mathrm{L})$ & 24 & 0 & 4 & 31 & 8 & 4 \\
$\mathrm{Sx}$ & 24 & 0 & 4 & 31 & 8 & 3 \\
$\mathrm{~T}$ & &
\end{tabular}

Table 6. Resistance spectrum to antibiotics of commercial use taken place by Vibrio cholerae of clinical and environmental samples

\begin{tabular}{cccc}
\hline Antibiotype & $\begin{array}{c}\text { Antibiotic } \\
\text { espectrum } \\
\text { of resístance }\end{array}$ & $\begin{array}{c}\text { Clinical } \\
\text { isolations }\end{array}$ & $\begin{array}{c}\text { Environmental } \\
\text { isolations }\end{array}$ \\
\hline I & T S C Sx W Fz & 1 & 0 \\
II & T S C Sx & 1 & 0 \\
III & T S Sx & 2 & 2 \\
IV & T S & 0 & 1 \\
V & W Fz & 1 & 0 \\
VI & A & 2 & 0 \\
VII & Fz & 1 & 0 \\
VIII & EM & 2 & 0 \\
IX & A W & 0 & 2 \\
& Total strains & 10 & 5 \\
\hline
\end{tabular}

$\mathrm{T}=$ tetracycline (30); $\mathrm{C}=$ chloramphenicol (30); $\mathrm{Sx}=$ sulfatrimethoprim (25); $\mathrm{S}=$ streptomycin (10); $\mathrm{A}=$ ampicillin (10); $\mathrm{Fz}=$ furazolidone (100); $\mathrm{W}=$ nalidixic acid (30); EM=erythromycin.

one could determine that those of environmental origin maintained the cloramfenicol sensibility, contrary to those of clinical origin (Tabla 3).

The results of the evaluation of strains of $V$. cholerae facing disks with $10 \mathrm{mgr}$ of concentration of the agent O/129 are described in the Table 4 which indicates that $100 \%$ of the strains of environmental origin exhibited resistance to this concentration of the compound, while those of clinical origin in both 1991 and 1998, showed resistance of 66,6\% and 85,7\% respectively. For the case of the concentration of $150 \mu \mathrm{g}$, the clinical strains of the year 1991 showed $100 \%$ of sensibility with zone diameter between 14 and $25 \mathrm{mM}$. The clinical and environmental strains of the year 1998 showed a resistance of $11,4 \%$ and $33,3 \%$ to the concentration of $150 \mu$ g respectively. In this group, the two strains of $V$. cholerae non-O1 were also included.

A direct relationship between the resistance and sensitivity that the strains of clinical origin presented, isolated in 1991 and 1998, was established against the agent O/129 (150 $\mu$ g), tetracycline and sulfa/trimethoprim (Table 5). Nine resistance

Table 7. Outcomes of Minimal Inhibitory Concentration (MIC) of clinical and environmental resistant strains of Vibrio cholerae by disk method in Agar

\begin{tabular}{|c|c|c|c|c|c|c|c|c|c|}
\hline \multirow{2}{*}{$\begin{array}{l}\text { V. cholerae } \\
\text { strains }\end{array}$} & \multicolumn{9}{|c|}{ MIC ( $\mu \mathrm{g} / \mathrm{mL})$} \\
\hline & TET & CLO & TRIM & SUL & AMP & SM & NAL & FUR & ERI \\
\hline $\begin{array}{l}\text { Clinical } 1991 \\
\text { n = 1 } \\
\text { Clinical } 1998\end{array}$ & S & S & S & S & $\mathrm{S}^{*}$ & S & S & S & S \\
\hline $\begin{array}{l}\mathrm{n}=9 \\
\text { Environmental } 1998\end{array}$ & 64 & 32 & 64 & $>128$ & $\mathrm{~S}^{*}$ & 128 & $S$ & 16 & $\mathrm{~S}^{*}$ \\
\hline $\mathrm{n}=5$ & 32 & $\mathrm{~S}$ & 64 & $>128$ & $\mathrm{~S}^{*}$ & 128 & 128 & $\mathrm{~S}$ & $\mathrm{~S}$ \\
\hline
\end{tabular}

TET=tetracycline; $\mathrm{CLO}=$ cloramfenicol; TRIM=trimethoprim; SUL=sulphamethoxasole; AMP=ampicillin; SM=streptomycin; $\mathrm{NAL}=$ Nalidixic acid; FUR=furazolidone; ERI=erythromycin. $\mathrm{S}=$ susceptible; $\mathrm{S}^{*}=$ susceptible with resistance values non confirmed by MIC. 
antibiotypes were determined. Four strains showed multiresistance: antibiotype I (T S C Sx M Fz); antibiotype II (T S C Sx) and antibiotype III (T S Sx) (Table 6).

To carry out the MIC, 15 strains with apparent resistance to some of the antibiotics tested (14 strains of 1998 and 1 of 1991) with the disk diffusion method in agar were evaluated, with 48 strains that presented intermediate and susceptibility features, which included 24 and 15 strains of clinical origin isolated respectively in 1998 and 1991 and 9 of environmental origin (1998).

In Table 7, the concentrations of antibiotics in which the growth of the strains is inhibited in study are shown. The highest MIC ( $>128 \mu \mathrm{g} / \mathrm{mL}$ ) was reached for sulfamethoxazole and streptomycin by clinical and environmental strains and for nalidixic acid for only one environmental strain.

\section{Discussion}

It is necessary to point out that there was not a remarkable variation with regard to their metabolism, as the one that could be expected with strains isolated in different periods of time, due to the establishment and adaptation of the bacteria in our environment. For the specific case of the tests of Voges Proskauer, Glicerol and growth to $6 \%$ of $\mathrm{NaCl}$, the behavior of $V$. cholerae in these is variable and these results coincides with those reported for the specie in Bergey's Manual [6]. Kay and Cabbage (1994), recommend the use of a great amount of consistent identification in 12 biochemical tests for the identification of V.cholerae and the performing of complementary tests only when the results do not coincide with those ones [20]. The use of 28 tests granted a margin of more accuracy to the identification of the strains in this study. The V. cholerae serogroup O1, that corresponds to the seventh pandemic, continues being the etiological agent of the cholera epidemic in Peru. This bacteria, since its appearance in those first months of 1991 [13], has still been producing sporadic epidemic outbreaks during the last years [14-15]. This specie that was presented initially as Inaba serotype in 1991, appeared in the following outbreak as Ogawa which corroborates the reported ability of $V$. cholerae not only to change serotype Inaba to Ogawa or vice versa but also to pass of smooth colonies to rough [21].

Their endemicity in our country is related with marked seasonal changes, especially to the El Niño Oscillation Southern (ENOS). The climatic changes of the year 1998 unchained by the ENOS have had a direct importance in the dissemination and the dynamics of transmission of infectious illnesses as the cholera. Colwell and Cabbage (1998), stand out the relationship of the climatic events with the emergency and dissemination of the cholera in America [22]. In our country the occurrence of diarrhoeic illnesses of bacterial ethiology and the temperature have always shown a direct relationship, which has been previously informed in several investigation projects [14-15]. The cholerae has a very particular behavior in terms of seasonal changes. Pathogens like E. coli and Salmonella, causing Acute Diarrhoeic Illness, according to the Ministry of Health [23], are frequently reported in the months of summer, but $V$. cholerae appears only in epidemic way when there is abrupt temperature changes associated to the ENOS [14-22].

In relation to the vibriostatic agent evaluation $\mathrm{O} / 129$, an increment of the resistance of the strains of 1991 in connection with those of 1998 was observed, to both concentrations of 10 and of $150 \mu \mathrm{g}$, for what it would not proper to be used as an additional test for the taxonomic determination of the species as it is suggested in the Bergey's Manual [6]. In different parts of the world several results have been reported in connection with the resistance from V.cholerae to this compound, which includes, in some cases the recovery from their sensibility to the vibriostatic agent [24].

The relationship among sulfa/trimethoprim, tetracycline and the agent $\mathrm{O} / 129$ in the concentration of $150 \mu \mathrm{g}$ is explained by picking up results of previous investigations in those that $\mathrm{R}$ plasmids for sulfa/trimethoprim and tetracycline have been isolated, which also contained resistance genes to the vibriostatic compound O/129 [10,11,25]. The relationship between the $0 / 129$ and the Sulfa/trimethoprim has also been reported for the serogroup $\mathrm{O} 139$ [26] and the resistance to both antibiotics for $V$. cholerae $\mathrm{O} 1$ was described during the ENOS 98 in Peru [27].

In relation to the tests of antimicrobial sensibility in vitro, you could determine an increment from the resistance to different antimicrobians of clinical use in strains isolated during the last epidemic outbreak of 1998 in comparison with the occurrence in 1991, in which an only strain showed resistance to ampicillin.

This increase of the antimicrobial resistance, is frequently reported in areas where the cholera is endemic, due to the constant treatment with certain antibiotics [28]. The antibiotics that were effective with all the studied strains were ciprofloxacin and doxycycline, which connected with other antibiotics as the fluoroquinolones are being evaluated nowadays to determine new alternatives in the treatment against the cholera but whose use is uncommon in our country [29-31]. In developed countries, these antibiotics would be probably the election drugs because they quickly reduce the fecal excretion of Vibrio, and they can cover a wide spectrum of enteropathogens including $V$. cholera. However, in Peru, the costs can be an important factor in the use of these antibiotics.

A comparison among the strains of environmental and clinical origin isolated in 1998, established a significant similarity comparing to the behavior from this bacteria to antibiotics. These results are reinforced by other investigators that also carried out the evaluation of the antimicrobial sensibility in strains of different origins [3], what suggests that these species does not lose its resistance capacity once the host is abandoned.

Out of the 9 antibiotypes exhibited in Table 6 , the first 4 antimicrobial spectra showed for the tetracycline and streptomycin like the antibiotics with more frequent resistance, 
followed by the sulfa/trimethoprim usually recommended in the treatment of the cholera, this was observed in strains of clinical origin as well as in the environmental ones. It is also necessary to highlight that the antibiotype III (T S Sx) was in clinical origin strains as well as in environmental ones, a genotypic characterization of these could determine it exists among them a near phylogenetic relationship that allows us to affirm the maintenance of toxigenic and resistant strains in aquatic reservoirs in our environment.

In the tests carried out to determine the MIC, the opposing concentration ranges have been similar enough to other investigation projects for the case of cloramfenicol, tetracycline, streptomycin and sulfamethoxazole for clinical and environmental strains [32].

Previous experiences using the technique of SDS-PAGE to evaluate total proteins of all the strains of $V$. cholerae studied in this report, the only one pattern shows us, in spite of the differences in relation to its origin, serotype and susceptibility to antimicrobians [33].

A study about phenotypic characterization of $V$. cholerae could provide excellent data on the behavior of both strains of environmental origin and clinical, as well as the evolution of these strains in our country, where they have been established in endemic form [34], thus contributing the epidemic study of the cholera that affects the Peruvian population and mainly the marginal population.

\section{Acknowledgements}

I thank to the Institute of Public Health (MINSA-Peru) for the contribution of strains of the epidemic of V. cholerae 1991, used study presently and to the Dr. Humberto Guerra, of the Institute of Tropical Medicine Alexander Von Humboldt of the Peruvian University Cayetano Heredia for their contributions and suggestions in the elaboration of the present project.

\section{References}

1. Bennish M. Cholera: Pathophysiology, Clinical, Features, and Treatment. Ch 15. In: Wachsmuth I.K., Blake P.A., Olsvik Ô. eds. Vibrio cholerae and Cholera - Molecular to global perspectives. Washington D.C.: American Society for Microbiology, 1994.

2. Yamai S., Okitsu T., Shimada T., Katsube T. Distribution of serogroups of Vibrio cholerae Non-O1, Non-O139 with specific reference to their ability to produce cholera toxin and addition of novel serogroups. Kansenshogaku-Zasshi 1997;71:1037-45.

3. Seas C., Gotuzzo E. Vibrio cholerae and other species. In: Yu V., Merigan T. Jr., Barriere S. ed. Antimicrobial Therapy and Vaccines. Baltimore, USA: Williams \& Wilkins, 1999.

4. Cavallo J., Niel L., Talarmin A., Dubrous P. Sensibilité aux antibiotiques de souches epidemiques de Vibrio cholerae et Shigella dysenteriae isolées dans les camps de refugiés rwandais aun Zaire. Med Trop Mars 1995;55:351-3.

5. Sathiyamurthy K., Purushshotaman A., Ramaiyan V. Antibiotic resistant of Vibrio cholerae in Parangipetti coastal environs, south east India. Microb Drug Resist 1997;3:267-70.

6. Holt J.G., Krieg N.R., Sneath P.H.A., et al. eds. Bergey's Manual of Determinative Bacteriology. Maryland, USA: Willliams \& Wilkins, 1994.
7. Huq A., Alam M., Parveen S., Colwell R. Occurrence of resistance to vibriostatic O/129 in Vibrio cholerae $\mathrm{O} 1$ isolated from Clinical and environmental samples in Bangladesh. J Clin Microbiol 1992;30:219-21.

8. Abbot S., Cheung W., Portoni B., Janda M. Isolation of vibriostatic agent O/129-resistance Vibrio cholerae Non-O1 from a patient with gastroenteritis. J Clin Microbiol 1992;30:1598-99.

9. Ramamurthy T., Pal A., Pal S. Nair G. Taxonomical implications of the emergence of high frequency of occurrence of 2,4diamino-6,7-diisopropylpteridine-resistant strains of Vibrio cholerae from clinical cases of cholera in Calcutta, India. J Clin Microbiol 1992;30:742-3.

10. Korichi M., Belchocine S., Rahal K. Plasmides inc J identifies pour la premiere fois dans Vibrio cholerae El Tor. Med Trop Mars 1997; $57: 249-52$.

11. Sow A., Cisse M., Gaye M., et al. Diversité bacterienne au cours de l'epidemie de cholera a Dakar, Senegal (1995-1996). Bull Soc Pathol Exot 1997;90:160-1.

12. Ministerio de Salud/Oficina de Defensa Nacional/OPS. Cap 11: Perú. En: Crónica de desastres-Fenómeno El Niño, 1997-1998. Washington, DC, USA: OPS, 2000.

13. Gotuzzo E., Cieza J., Estremadoyro L., Seas C. Cholera. Lessons from the Epidemic in Perú. Infect Dis Clin North Am 1994;8:183205.

14. Ibarra J., Delgado A., Alvarado D. Vibrios no epidémicos y Vibrio cholerae O1 asociados a Enfermedad Diarreica Aguda Evento Climatológico "El Niño" 1998 - Hospital Dos de Mayo. Revista Anales Facultad Medicina 1999;60:251-6.

15. Clendenes M., Carballo F., Huaroto L., et al. Epidemic outbreak of acute diarrhea disease in adults in a emergency room. Resumen PS 048, Proc. 24 ${ }^{\text {th }}$ International Congress of Internal Medicine. International Society of Internal Medicine. Lima-Perú 1998.

16. UNESCO/MIRCEN/FAO/UNEP/IUMS/UNIV.MARYLAND. Workshop schedule. International Workshop on Environmental and Aquatic Microbiology and Biotechnology. Maryland, USA: University of Maryland, 1993.

17. Bauer A., Kirby W., Sherris J., Turck M. Antibiotic susceptibility testing by a standarized sing disk method. Am J Clin Pathol 1966; $45: 493-6$.

18. National Committee for Clinical Laboratory Standards. Performance standards for antimicrobial disk susceptibility tests, $4^{\text {th }}$ ed. Approved stand. NCCLS document M100-54. Pennsylvania, USA: NCCLS, 1992.

19. National Committee for Clinical Laboratory Standards. Performance Standards for antimicrobial susceptibility testing; Fourteenth informational supplement. NCCLS document M100S14. Pennsylvania, USA: NCCLS, 2004.

20. Kay B.A., Bopp C.A., Wells J.G. Isolation and Identification of Vibrio cholerae $\mathrm{O} 1$ from fecal specimens. Ch 1. In: Wachsmuth I.K., Blake P..A, Olsvik Ô. Eds. Vibrio cholerae and Cholera Molecular to global perspectives. Washington DC, USA: American Society for Microbiology, 1994.

21. Manning P., Stroeher M.R. Molecular basis for O-antigen biosynthesis in Vibrio cholerae O1: Ogawa-Inaba switching. Ch 6. In: Wachsmuth I.K., Blake P. A., Olsvik Ô., ed. Vibrio cholerae and cholera - Molecular to global perspectives. Washington DC, USA: American Society for Microbiology. 1994.

22. Colwell R., Epstein P., Gubler D., et al. Global climate change and infections diseases. Emerg Infect Dis 1998;4:451-2.

23. Ministerio de Salud-Perú. Análisis epidemiológico de las enfermedades vigiladas por la Red Nacional de Epidemiología I Semestre. Boletín Epidemiológico 1999;2:3-7.

24. Ramamurthy T., Pal A., Pal S., Nair G. Taxonomical implications of the emergence of high frequency of occurrence of 2,4diamino-6,7-diisopropylpteridine-resistant strains of Vibrio cholerae from clinical cases of cholera in Calcutta, India. J Clin Microbiol 1992;30:742-3. 
25. Falbo V., Carattoli A., Tosini F., et al. Antibiotic Resístanse Conferred by a Conjugative Plasmid and a Class I Integron in Vibrio cholerae O1 El Tor Strains Isolated in Albania and Italy. Antimicro Agent Chemotherapy 1999;43:693-6.

26. Albert M., Bhuiyan N., Talukder K., et al. Phenotypic and genotypic changes in Vibrio cholerae O139 Bengal. J Clin Microbiol 1997;35:2588-92.

27. Ibarra J.O., Alvarado D.E. Evaluación de la resistencia a 2,4Diamino-6,7-Diisopropilpteridina en estirpes de Vibrio cholerae aisladas durante el ENOS 98 de muestras clínicas y ambientales. En: Libro de resúmenes del Seminario Taller: Impacto de los eventos "El Niño Oscilación Sur" sobre la diversidad biológica de América Latina. Lima, Perú: CONCYTEC-RIBEN, 1999.

28. Podosinnikova L., Mazrukho B., Lomov I., et al. Nekotoye osobennosti Vibrio cholerae, vydelennykh v Dagestane v 1994 g. Zh Mikrobiol. Epidemiol. Immunol $1995 ; 2: 74-8$.
29. Doganci L., Gun H., Baysallar M., et al. Short- term quinolonas for successful erradication of multiply resistant Vibrio cholerae in adult patients. Scand. J Infect Dis 1995;27:425-6.

30. Gotuzzo E., Seas C., Echevarria J., et al. Ciprofloxacin for the treatment of cholera: a randomized, double-blind, controlled clinical trial of a single daily dose in Peruvian adults Clin Infect Dis 1995;20:1485-90.

31. Yamamoto T., Nair G., Albert M., et al. Survey of in vitro susceptibilities of Vibrio cholerae $\mathrm{O} 1$ and $\mathrm{O} 139$ to antimicrobial agents. Antimicrob Agents Chemother 1995;39:241-4.

32. Korichi M., Belchocine S., Rahal K. Plasmides inc J identifies pour la premiere fois dans Vibrio cholerae El Tor Med Trop Mars 1997;57:249-52.

33. Ibarra J., Flores L., García R., Alvarado D. Estudio preliminar de la resistencia de V.cholerae O1, brote epidémico 1998, a antimicrobianos. Revista Peruana de Biología 2000;7:83-6.

34. Gil A.I., Louis V.R., Rivera I.N.G., et al. Occurrence and distribution of Vibrio cholerae in the coastal environment of Peru. Environ Microbiol 2004;6:699. 